Article

\title{
The Role of Gangue Mineralogy on Flowsheet Development in Fluorite Processing
}

\author{
Jestos Taguta ${ }^{1, *}$, Kebone Carol Teme ${ }^{2}$ and Portia Ngobeni ${ }^{1}$ \\ 1 Mineral Processing Division, Mintek, Private Bag X3015, Randburg 2125, South Africa; \\ portiamal@mintek.co.za \\ 2 Jubilee Metals Group, 7 Einstein St, Highveld Techno Park, Centurion 0157, South Africa; \\ Kteme@jubileemetalsgroup.com \\ * Correspondence: Jestost@mintek.co.za; Tel.: +27-011-709-4307
}

Received: 21 January 2020; Accepted: 20 February 2020; Published: 6 March 2020

\begin{abstract}
Fluorite, $\mathrm{CaF}_{2}$, is considered a strategically important mineral as it is a raw material for many strategic industries. Froth flotation is reported to be the most efficient and economically viable process for the production of an acid-grade product with a $\mathrm{CaF}_{2}$ content of at least $97 \%$. Selective flotation of fluorite from gangue minerals, e.g., calcite and barite, is challenging because these minerals have similar physicochemical properties. This study employed batch flotation tests coupled with mineralogical analysis to design suitable customised flowsheets and efficiently optimised reagent regimes for optimum production of acid-grade fluorite concentrate from two different fluorite ores by the froth flotation process. The effect of pulp temperature on fluorite flotation was investigated in this study with the objective of lowering pulp temperatures in fluorite flotation. The results showed that an acid-grade $\mathrm{CaF}_{2}$ concentrate could be obtained from the flotation of both ores at ambient pulp temperatures. This eliminates the requirement for high-temperature pulp treatment, which would result in a significant reduction in thermal energy costs. This study showed that an understanding of gangue mineralogy is key to process optimisation for acid-grade $\mathrm{CaF}_{2}$ production. Although an acid-grade $\mathrm{CaF}_{2}$ concentrate could be produced from both ores, the flowsheets and reagent regimes were markedly different. For instance, the production of an acid-grade $\mathrm{CaF}_{2}$ product from a high quartz and calcite ore was achieved by employing a simple rougher-multiple cleaner flotation circuit using tannin and sodium silicate as calcite and quartz depressants, respectively. On the other hand, the production of an acid-grade $\mathrm{CaF}_{2}$ product from the flotation of the pyritic ore required a pre-sulphide flotation stage for upfront sulphur removal and the use of a sulphide depressant. Multiple stages of cleaning were required for improved selectivity in the flotation of both ores.
\end{abstract}

Keywords: froth flotation; fluorite; selectivity; depressant; gangue; mineralogy

\section{Introduction}

Fluorite, $\mathrm{CaF}_{2}$, is considered a strategically important mineral that is used in the production of hydrofluoric acid and as a flux agent in the steel making industry. Fluorite ores are beneficiated through different techniques, viz., froth flotation, and gravity and magnetic concentration depending on the end use of the fluorite. Froth flotation is reported to be the most efficient and economically viable process for the production of an acid-grade product with a $\mathrm{CaF}_{2}$ content of at least $97 \%$.

The mineralogical compositions of current fluorite deposits are becoming increasingly complex, making the selective flotation of fluorite from gangue even more challenging. Typical gangue minerals include calcite, quartz and barite [1]. Some sulphide gangue minerals, such as pyrite, galena and sphalerite, may also be present in fluorite ores. Selective flotation of fluorite from the gangue e.g., calcite and barite, is challenging because all these minerals have similar physicochemical properties 
arising from $\mathrm{Ca}^{2+}$ surface cations. The $\mathrm{Ca}^{2+}$ cations react with the commonly used fatty acid collectors resulting in these minerals exhibiting a similar flotation response, translating to low-grade $\mathrm{CaF}_{2}$ concentrates. The calcite and barite depressants also inhibit fluorite flotation, thus careful depressant selection is central to selective fluorite flotation. The presence of sulphidic gangue minerals in fluorite ores results in $\mathrm{CaF}_{2}$ concentrate with sulphur content higher than the market specification of $0.03 \%$. It is therefore necessary to control the sulphidic gangue in fluorite flotation. Some fluorite processing plants are located in northern China, which is characterised by long cold winters, necessitating thermal heating of the ore slurry translating to high energy costs. Apart from the proper selection of depressants, high-temperature pulp treatment has also been shown to improve the selectivity in fluorite flotation [2-4]. There is therefore a need to come up with customised flowsheets and efficient optimised reagent regimes for improved selectivity and reduced energy costs in fluorite flotation [4-6].

In this study, the role of gangue mineralogy in fluorite flotation was investigated. It was proposed that flowsheet and reagent regime selection depend on the type and proportion of gangue minerals present in an ore. This paper presents results of batch scale flotation tests for two different fluorite ores sourced from different geographical locations. The effects of pulp temperature, reagent types and flowsheet on flotation of the two fluorite ores were systematically investigated. Optimisation of different reagent regimes was achieved by varying reagent dosages in order to improve fluorite grade-recovery relationships.

\section{Materials and Methods}

\subsection{Sample Preparation, Mineralogical and Chemical Analysis}

Two fluorspar ores sourced from different geographical locations within Morocco and South Africa (thereafter referred to as A and B, respectively, in this manuscript) were investigated in this study. The ores were crushed to minus $1.7 \mathrm{~mm}$ for flotation tests using a jaw crusher. A rotary splitter was then used to divide the ores into $1 \mathrm{~kg}$ representative samples. The mineralogical analysis of the representative sized particles of the ores was conducted using a field emission gun automated quantitative electron scanning microscopy (QEMSCAN, FEI company, Brisbane, Australia) and X-ray diffraction (XRD). XRD was conducted to identify the mineral phases and composition in a given sample, the result of which was used to set up mineral identification parameters on the QEMSCAN. The particle mineral maps were produced using the particle map analysis (PMA) measuring mode, from which the bulk modal proportions of the minerals present, the liberation and association information of fluorine-bearing minerals were derived. The major elemental composition of the fluorite ores was determined using the $\mathrm{X}$-ray fluorescence $(\mathrm{XRF})$ method, which required the double Ca titration method for the removal of soluble $\mathrm{Ca}$ from carbonates, followed by the determination of $\mathrm{Ca}$ associated with fluorine.

\subsection{Reagents}

The chemical reagents used in this study are shown in Table 1. Reagent selection was conducted in close consultation with various flotation reagent suppliers based on their database and experience on treatment of similar ore types. Flotinor 7243 is a mixture of lauryl polyglycol ether carboxylic acid (LCA) and nonylphenol polyglycol ether (NPE). A variety of gangue depressants were tested in this study based on the type of gangue minerals present in each ore (Section 3.1). All the reagents were dosed based on active content, and standard tap water was used as the medium in all flotation experiments. 
Table 1. List of reagents used in this study.

\begin{tabular}{|c|c|c|c|c|c|}
\hline Reagent & Chemical Name/Formula & Use & Purity (\%) & Targeted Ore & Supplier \\
\hline Flotinor 7243 & Fatty acid & Fluorite collector & $\begin{array}{l}\text { 15-25 LCA; } \\
\text { 5-15 NPE }\end{array}$ & $\mathrm{A}$ & Clariant \\
\hline Sylfat FA 2 & Tall oil fatty acid & Fluorite collector & 100 & B & Arizona Chemicals, USA \\
\hline Sodium fluorite & $\mathrm{NaF}$ & Fluorite activator & 100 & $A \& B$ & Hyperion chemicals \& consulting \\
\hline Sodium amyl xanthate & $\mathrm{C}_{3} \mathrm{H}_{5} \mathrm{NaOS}_{2}$ & Sulphide collector & 99.9 & B & Senmin \\
\hline Sodium hydrosulphide & $\mathrm{NaHS}$ & Sulphide activator & $\begin{array}{l}75 \mathrm{NaHS} ; 3 \mathrm{Na}_{2} \mathrm{~S} \\
15 \text { ppm Fe content }\end{array}$ & B & Axis house \\
\hline Soda ash & $\mathrm{Na}_{2} \mathrm{CO}_{3}$ & $\mathrm{pH}$ modifier & 100 & $A \& B$ & Hyperion chemicals \& consulting \\
\hline Pionerra F250 - & Sodium lignin sulphonate & Barite and sulphide depressant & 100 & $A \& B$ & Hyperion chemicals \& consulting \\
\hline Tan XS & Acacia mearnsii extract, bisulfited & Calcite depressant & 64 & $A \& B$ & Bondtite (Pty) Limited \\
\hline Sodium silicate & $\mathrm{Na}_{2} \mathrm{SiO}_{3}$ & Silica depressant & 40 & $A \& B$ & Hyperion chemicals \& consulting \\
\hline
\end{tabular}




\subsection{Batch Flotation Tests}

The Denver D12 flotation machine was used for the batch flotation testwork at an impeller speed of $1500 \mathrm{rpm}$. Milling tests were conducted on the ore to establish the milling time required to achieve targeted grinds for the two different ores (Section 3.2). The market specification demands that particle size distribution (PSD) of the product be $80 \%$ passing $65 \mu \mathrm{m}$. Accordingly, this study investigated the flotation response of samples whose PSDs were coarser than $80 \%$ passing $65 \mu \mathrm{m}$. The market's product particle size distribution (PSD) specification was $80 \%$ passing $65 \mu \mathrm{m}$ and hence grinds coarser than 65 $\mu \mathrm{m}$ were investigated in this study. High chrome steel rods were used as grinding media and milling was conducted at 50\% solids' concentration in the mill. Batch flotation tests were conducted on $1 \mathrm{~kg}$ feed samples that were rod milled to a given grind. The milled slurry was conditioned in a Denver D12 flotation machine, with a slurry density of 33\% solids in the rougher and $18 \%$ in the cleaners. All flotation reagents were prepared at $1 \%$ strength with exception of the fatty acids, which were added neat. A given amount of depressant was added followed by the addition of a given amount of collector. Sodium carbonate was used as a $\mathrm{pH}$ modifier in the rougher, targeting a $\mathrm{pH}$ of 9.5. Pulp temperature was adjusted to a targeted value using a water bath. The concentrates and the tailings were dried separately. The dry mass of the concentrates and tailings were determined to calculate the recoveries. The concentrates were assayed for $\mathrm{CaF}_{2}, \mathrm{CaCO}_{3}, \mathrm{SiO}_{2}$ and $\mathrm{S}$ using the techniques highlighted in Section 3.1. Fluorite grade-recovery curves were used as primary responses to compare the performances of different flowsheets and reagent regimes.

\section{Results and Discussion}

\subsection{Mineralogical and Chemical Analysis}

The head grade, mineralogical composition and the mineral phase proportions of ores A and B are shown in Table 2 and Figure 1. Liberation characteristics of both ores were determined at a grind of $80 \%$ passing $150 \mu \mathrm{m}$.

Table 2. Chemical analysis of the fluorspar ores A and B.

\begin{tabular}{ccccccccccc}
\hline Ores & $\mathrm{CaF}_{2}$ & $\mathbf{M g O}$ & $\mathrm{Al}_{\mathbf{2}} \mathbf{O}_{\mathbf{3}}$ & $\mathbf{S i O}_{\mathbf{2}}$ & $\mathrm{CaCO}_{3}$ & $\mathrm{Fe}$ & $\mathbf{S}$ & $\mathbf{B a S O}_{4}$ & $\mathbf{K}_{\mathbf{2}} \mathbf{O}$ & $\mathbf{M n O}$ \\
\hline $\mathbf{A}$ & 30.4 & 0.24 & 1.32 & 26.1 & 36.2 & 0.33 & 0.41 & 1.45 & 0.05 & 0.05 \\
$\mathbf{B}$ & 26.9 & 10.8 & 0.83 & 6.32 & 54.3 & 5.97 & 4.10 & 0.22 & 0.19 & 0.58 \\
\hline
\end{tabular}

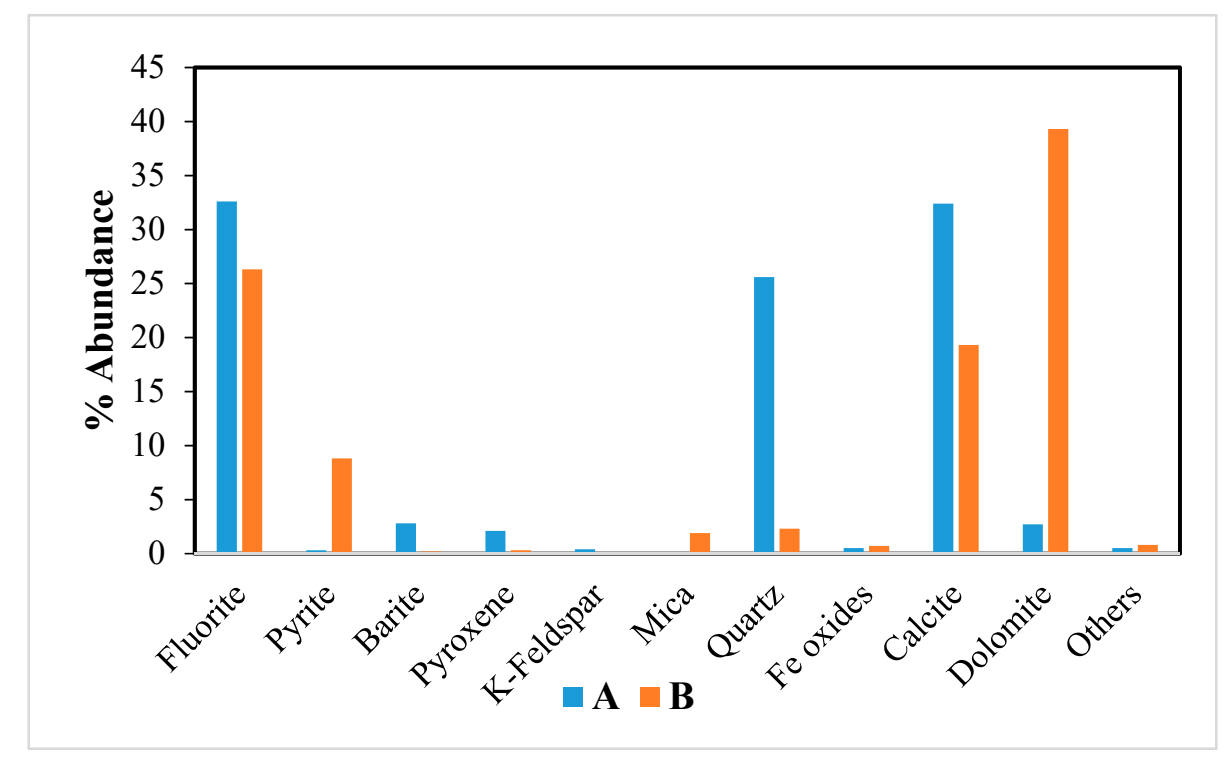

Figure 1. Bulk mineralogical analysis of fluorspar ores A and B in mass \%. 
It is clear from Table 2 and Figure 1 that the $\mathrm{CaF}_{2}$ grades were relatively similar in both ores. However, there were significant differences in terms of the type and proportion of the gangue minerals present in both ores. Ore A had higher quartz and calcite contents compared to ore B. In fact, the quartz and calcite contents of ore A were approximately eleven times and twice those of ore B, respectively. On the other hand, ore B had higher pyrite and dolomite contents compared to ore A. It is clear that ore B had 30 times the pyrite content of ore A. The dolomite content in ore B was 13 times that in ore A. The differences in the mineralogical contents of the two ores are expected to affect flowsheet and reagent regime selection to process both ores.

\subsection{Flowsheet Development}

The development of suitable flowsheets and optimised reagent regimes for the processing of ores A and B was based on the ores' mineralogical characteristics. Preliminary reagent scouting tests showed that Flotinor 7243 and Arizona Sylfat FA2, both fatty acid collectors, produced superior metallurgical results for the processing of ore A and B, respectively. The results were not presented not only for the brevity of the manuscript but also because this paper focussed only on the role of gangue mineralogy on flowsheet development for fluorite processing. Preliminary flotation testwork also showed that six cleaning stages were required to produce an acid-grade $\mathrm{CaF}_{2}$ product from both ores.

\subsubsection{Flowsheet for Ore A}

The mineralogical and chemical analysis results depicted in Table 2 and Figure 1 indicate that for ore A to be upgraded, quartz and calcite minerals are to be separated from the fluorite during flotation. Tannins have been shown to be strong calcite depressants [6,7], while sodium silicate is reported to be an effective silica depressant [8,9]. In terms of liberation characteristics at a grind of $80 \%$ passing 150 $\mu \mathrm{m}, 90 \%$ of the fluorite grains were fully liberated, with less than $15 \%$ of fluorite grains showing an intimate association with calcite and other silicate gangue minerals. Therefore, a grind of $80 \%$ passing $150 \mu \mathrm{m}$ was assumed suitable to achieve adequate liberation of selective fluorite flotation. A simple flotation flowsheet, shown in Figure 2, was proposed for processing ore A. Flotation times were as follows: $4 \mathrm{~min}$ for the rougher; $4 \mathrm{~min}$ for cleaners 1 and 2; $3 \mathrm{~min}$ for cleaners 3 and $4 ; 2 \mathrm{~min}$ for cleaners 5 and 6 .

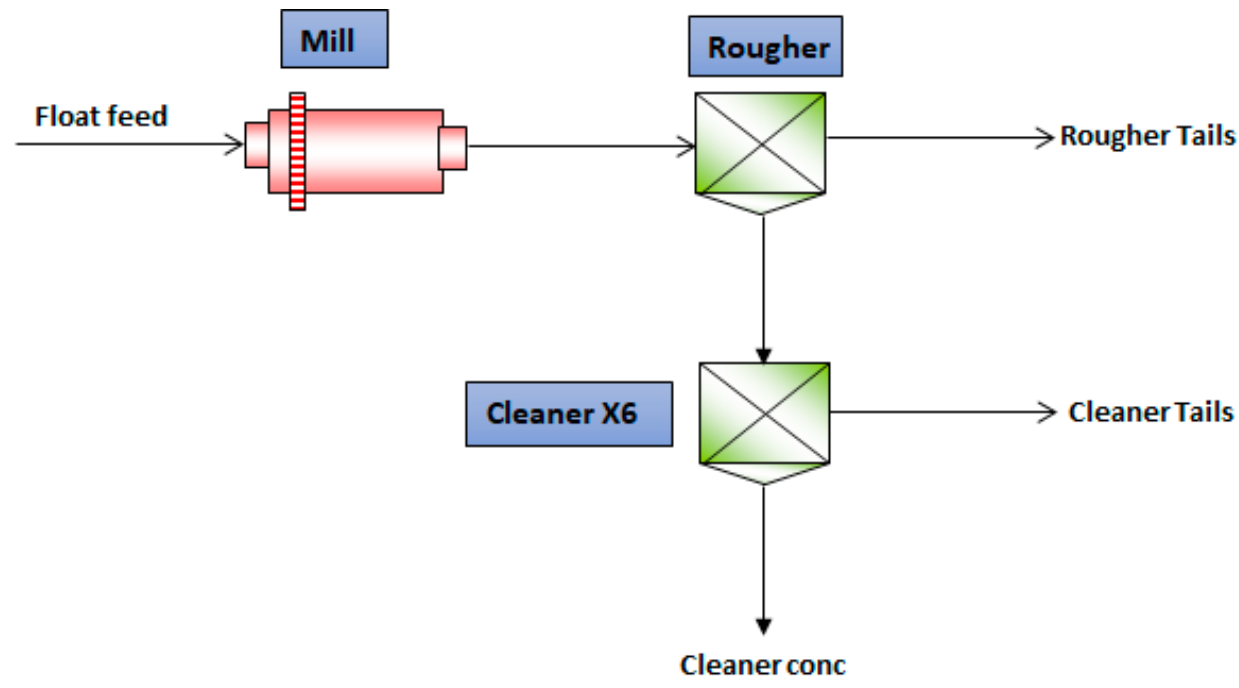

Figure 2. Flowsheet for the processing of ore A.

\subsubsection{Flowsheet for Ore B}

The beneficiation of ore B required the depression of pyrite, calcite and dolomite. Similar to ore A, tannins and sodium silicate were used as calcite and silica depressants [6-9]. Lignin sulphonate is reported to be an effective pyrite depressant [10]. In terms of liberation characteristics at a grind of 
$80 \%$ passing $150 \mu \mathrm{m}, 25 \%$ of fluorite grains were fully liberated with $75 \%$ of fluorite grains reporting as middlings and $42 \%$ fluorite being associated with major gangue. Because of the poor degree of liberation, ore $\mathrm{B}$ might require concentrate regrinding to liberate the fluorite grains as opposed to ore A. To determine the optimum grind for ore B, the effect of grind on the grade-recovery relationship in rougher flotation was investigated and the results are shown in Table 3.

Table 3. Effect of grind on $\mathrm{CaF}_{2}$ grade-recovery relationship for ore B using Arizona Sylfat FA2 collector in rougher cells.

\begin{tabular}{cccc}
\hline $\mathbf{P}_{\mathbf{8 0}}$ Grind $(\boldsymbol{\mu m})$ & Mass Pull (\%) & $\mathbf{C a F}_{\mathbf{2}}$ Grade (\%) & $\mathbf{C a F}_{\mathbf{2}}$ Recovery (\%) \\
\hline 125 & 46.6 & 32.8 & 86.5 \\
106 & 37.1 & 41.9 & 86.0 \\
90 & 44.1 & 34.0 & 89.6 \\
75 & 52.3 & 30.2 & 88.7 \\
\hline
\end{tabular}

Table 3 shows that the rougher $\mathrm{CaF}_{2}$ recoveries for $\mathrm{P}_{80}$ grinds of $125 \mu \mathrm{m}$ and $106 \mu \mathrm{m}$ were similar at $86 \%$, while for $\mathrm{P}_{80}$ of $90 \mu \mathrm{m}$ and $75 \mu \mathrm{m}$ the rougher $\mathrm{CaF}_{2}$ recoveries were similar at $89 \%$. The rougher $\mathrm{CaF}_{2}$ grades decreased in the following order: $\mathrm{P}_{80}=106 \mu \mathrm{m}>\mathrm{P}_{80}=90 \mu \mathrm{m}>\mathrm{P}_{80}=125 \mu \mathrm{m}>\mathrm{P}_{80}$ $=75 \mu \mathrm{m}$. Because it produced the highest $\mathrm{CaF}_{2}$ grade at reasonably high $\mathrm{CaF}_{2}$ recoveries, the $80 \%$ passing $106 \mu \mathrm{m}$ grind was selected as the optimum grind for further flotation testwork with a view to improving metallurgical performance.

Different process routes were considered for the removal of the pyritic gangue in ore B. The first route was through the selective depression of the pyritic gangue using the lignin sulphonate depressant, employing the simple flowsheet shown in Figure 2. The second route was an upfront removal of the pyritic gangue using a pre-sulphide flotation cell as shown in Figure 3. The second route used $\mathrm{NaHS}$ as a sulphide activator $[2,11]$ at a low dosage of $15 \mathrm{~g} / \mathrm{t}$ and potassium amyl xanthate (PAX) as a sulphide collector [12] in a pre-sulphide flotation cell. A higher NaHS dosage would be detrimental as it would depress the pyrite. NaHS functions by either cleaning or sulphidising the pyrite surface and hence improving the pyrite floatability. Flotation times were as follows: $6 \mathrm{~min}$ for the pre-sulphide rougher; $4 \mathrm{~min}$ for the rougher; $4 \mathrm{~min}$ for cleaners 1 and 2; $3 \mathrm{~min}$ for cleaners 3 and 4; 2 min for cleaners 5 and 6 . The metallurgical performance of the two process routes was evaluated and the results are presented in Table 4 . Table 4 shows, that although both process routes produced an acid-grade $\mathrm{CaF}_{2}$ product, the pre-sulphide flotation route produced $50 \%$ less sulphur content compared to the selective depression route. The pre-sulphide flotation route produced higher $\mathrm{CaF}_{2}$ recovery and grade than the selective depression route. It is clear that the pre-sulphide flotation route was the most effective means of removing the pyritic gangue from the fluorite ore and hence the flowsheet in Figure 3 was used for further optimisation tests.

Table 4. Comparison of the metallurgical performance different process routes in terms of pyrite removal using lignin sulphonate depressant at $170 \mathrm{~g} / \mathrm{t}$ dosage for ore B.

\begin{tabular}{cccc}
\hline \multirow{2}{*}{ Process Route } & \multicolumn{2}{c}{ Grade (\%) } & Recovery (\%) \\
\cline { 2 - 4 } & $\mathrm{CaF}_{\mathbf{2}}$ & $\mathrm{S}$ & $\mathrm{CaF}_{\mathbf{2}}$ \\
\hline No pre-sulphide float & 96.8 & 0.14 & 75.1 \\
Pre-sulphide float & 97.0 & 0.07 & 78.9 \\
\hline
\end{tabular}

Although the pre-sulphide flotation route was successful in reducing the pyritic gangue reporting to the $\mathrm{CaF}_{2}$ concentrate, the sulphur content was still higher than the market specification of at most $0.03 \%$. Therefore, optimisation tests were conducted to reduce the sulphur content in the $\mathrm{CaF}_{2}$ concentrate. 


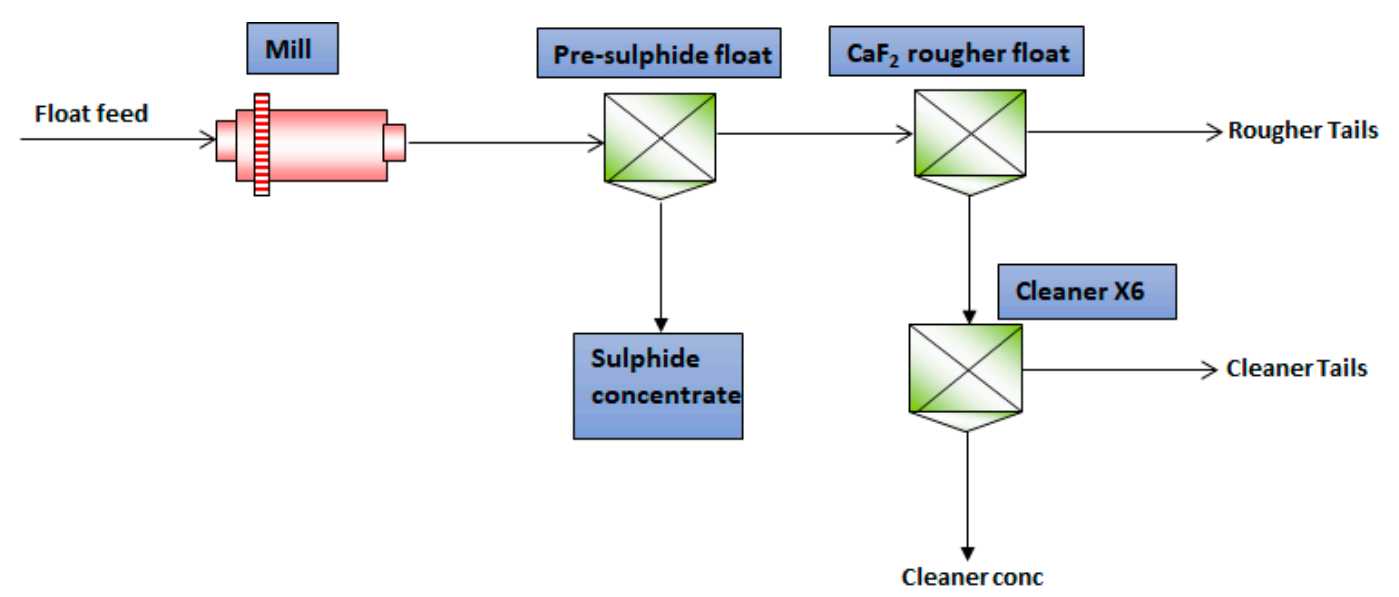

Figure 3. Flowsheet for the processing of ore B, which includes a pre-sulphide flotation stage, fluorite roughing and sequential cleaning.

\subsection{Effect of Pulp Temperature}

Figure 4 shows the effect of pulp temperature on the $\mathrm{CaF}_{2}$ grade-recovery relationship for ore A using the Flotinor 7243 collector at $300 \mathrm{~g} / \mathrm{t}$ dosage. The objective was to evaluate the affinity and the subsequent efficiency of the collector towards different minerals within the ore as a function of pulp temperature. Figure 4 shows that as the pulp temperature increases, the $\mathrm{CaF}_{2}$ recovery increases, while the $\mathrm{CaF}_{2}$ grade decreases. It is clear from Figure 3 that although the $\mathrm{CaF}_{2}$ recovery was low around $56 \%$, the product grade met the market specification of $97 \% \mathrm{CaF}_{2}$ at $20^{\circ} \mathrm{C}$. However, it was not possible to produce the acid-grade concentrate at $40{ }^{\circ} \mathrm{C}$. In order to investigate whether the observed results were ore-specific or not, the effect of pulp temperature was also investigated for ore B using a different fatty acid collector, Sylfat FA2 at $300 \mathrm{~g} / \mathrm{t}$ dosage, and the results are presented in Figure 5.

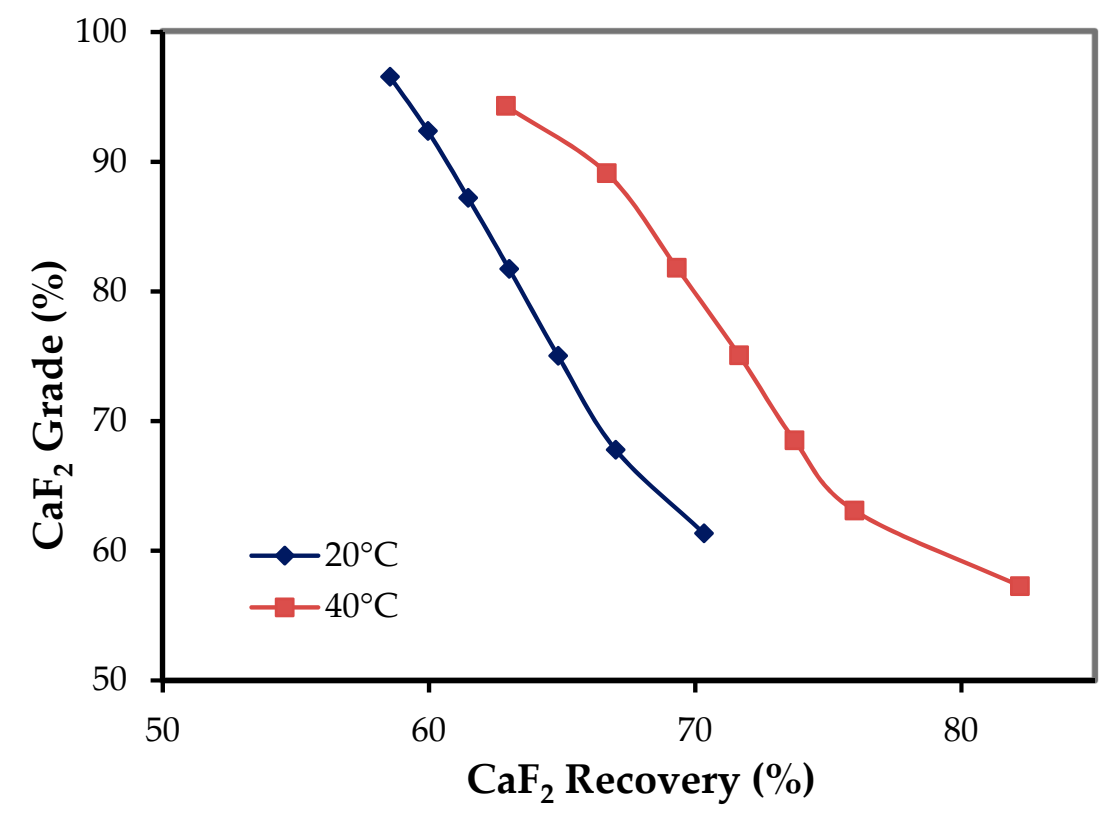

Figure 4. Effect of pulp temperature on the grade-recovery relationship for ore A.

The results in Figure 5 show that an acid-grade concentrate with a grade of $97 \% \mathrm{CaF}_{2}$ can be attained at $75 \%$ and $85 \%$ recoveries using the Sylfat FA2 collector at $20{ }^{\circ} \mathrm{C}$ and $40{ }^{\circ} \mathrm{C}$, respectively. A further increase of the pulp temperature to $60^{\circ} \mathrm{C}$ resulted in a significant increase in $\mathrm{CaF}_{2}$ recovery, 
but at the expense of $\mathrm{CaF}_{2}$ grade. It was therefore not possible to produce an acid-grade concentrate at $60{ }^{\circ} \mathrm{C}$ using the Sylfat FA2 collector.

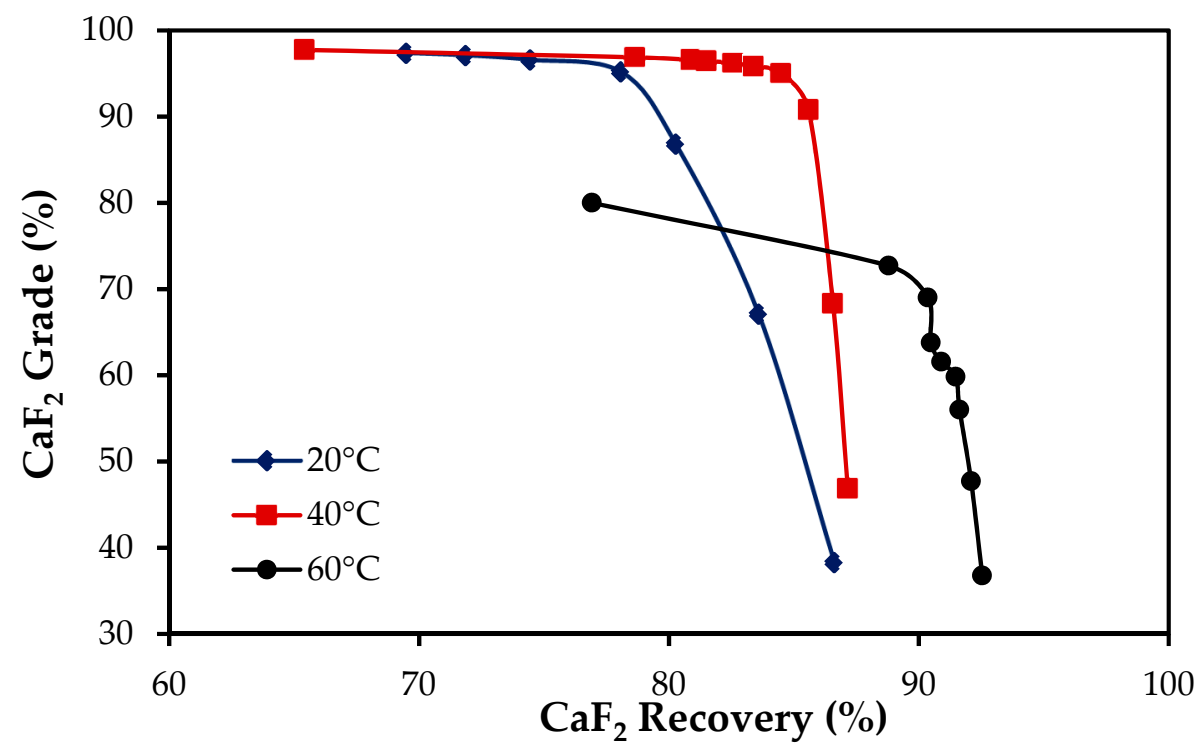

Figure 5. Effect of pulp temperature on $\mathrm{CaF}_{2}$ grade-recovery relationship for ore $\mathrm{B}$.

It has been observed from Figures 4 and 5, that as the pulp temperature increases, the $\mathrm{CaF}_{2}$ recovery increases, while the $\mathrm{CaF}_{2}$ grade decreases for both ores. Thus, the results are not ore-specific. Similar observations were made by [4], who showed that better fluorite selectivity in carbonate-fluorite ores is achievable at low temperatures. The same finding was made by [3] in their investigation on a fluorite ore from China using sodium naphthenate and salted copper sulphate as collector and depressant of phosphate gangue minerals, respectively. The results presented in both Figures 4 and 5 suggest that operating at lower temperatures would be more favourable to produce an acid-grade fluorite product. The results therefore show that both Flotinor 7243 and Sylfat FA2 can be effectively used as collectors in the flotation of ore $\mathrm{A}$ and $\mathrm{B}$, respectively, to produce acid-grade $\mathrm{CaF}_{2}$ concentrate at low pulp temperatures. Besides the benefit of increased selectivity, operating at low pulp temperatures would result in a significant reduction in energy costs in fluorite flotation. This is especially true for most fluorite processing plants located in northern China, which are characterised by long cold winters. In such plants, energy consumption is high due to heating of the ore slurry in flotation circuits for efficient separation. The use of the Flotinor 7243 and Sylfat FA2 collectors therefore eliminates the need for high-temperature pulp treatment, and thus a significant reduction in energy costs.

To understand the reason behind the loss of selectivity as pulp temperature increases for ore B, the behaviour of gangue minerals as a function of pulp temperature was investigated, and the results are presented in Table 5 . Table 5 shows that the calcite contamination increased with increasing pulp temperature. The increase in $\mathrm{CaF}_{2}$ recoveries with increasing pulp temperature could be due to an increase in the hydrophobicity and subsequent floatability of $\mathrm{CaF}_{2}$ as pulp temperature increases. This could be a result of improved dispersion of the collector throughout the pulp at high pulp temperatures.

Table 5. Effect of temperature on mass pull and gangue (calcite) contamination.

\begin{tabular}{ccccc}
\hline \multirow{2}{*}{ Temperature $\left({ }^{\circ} \mathbf{C}\right)$} & Mass Pull (\%) & \multicolumn{2}{c}{ Grade (\%) } & \multirow{2}{*}{ CaF $_{2}$} \\
\cline { 3 - 4 } & & $\mathbf{C a F}_{2}$ & $\mathbf{C a C O}_{3}$ & \\
\hline 20 & 11.8 & 97.4 & 1.34 & 69.5 \\
40 & 12.9 & 97.8 & 2.63 & 65.4 \\
60 & 19.1 & 80.3 & 10.3 & 76.9 \\
\hline
\end{tabular}


Improved collector dispersion and increased rate of mineral-collector interactions at high temperatures may promote the unselective adsorption of the fatty acid collector onto the gangue minerals. This renders the gangue minerals floatable, and hence the observed increase in gangue dilution of the $\mathrm{CaF}_{2}$ concentrate as pulp temperature increases. A similar finding was made by [13] in ilmenite flotation, where they observed the improved floatability of feldspar and biotite gangue minerals as pulp temperature was increased, resulting in reduced low-grade ilmenite concentrates.

\subsection{Effect of Fluorite Activation on Fluorite Flotation}

The addition of sodium fluoride, $\mathrm{NaF}$, as a fluorite activator on the flotation performance of both ores A and B was investigated in the rougher flotation cell and the results are shown in Table 6 . It is clear from Table 6 that increasing NaF dosage from 0 to $500 \mathrm{~g} / \mathrm{t}$ resulted in a slight increase in the recovery of $\mathrm{CaF}_{2}$ but a significant increase in the concentrate grade for ore $\mathrm{A}$. In fact, the concentrate grade was increased by more than $12 \%$. The significant increase in $\mathrm{CaF}_{2}$ grade was accompanied by around a 50\% decrease in silica and calcite gangue content. However, a further $50 \%$ increase in the $\mathrm{NaF}$ dosage resulted in a $3 \%$ drop in the $\mathrm{CaF}_{2}$ grade. This was clearly due to the increase in the recovery of gangue at high $\mathrm{NaF}$ dosages.

It is also clear from Table 6 that $\mathrm{CaF}_{2}$ recovery dropped by almost $50 \%$ when $\mathrm{NaF}$ was added to the roughers for ore B. Furthermore, gangue content increased with the addition of NaF. This shows that the use of $\mathrm{NaF}$ at $500 \mathrm{~g} / \mathrm{t}$ dosage had a detrimental effect on fluorite recovery from ore $\mathrm{B}$.

Table 6. Effect of fluorite activation using $\mathrm{NaF}$ on $\mathrm{CaF}_{2}$ grade and recovery for ore $\mathrm{A}$ and $\mathrm{B}$.

\begin{tabular}{ccccccc}
\hline \multirow{2}{*}{ Ore Type } & \multirow{2}{*}{ NaF Dosages (g/t) } & \multirow{2}{*}{ Mass Pull (\%) } & \multicolumn{3}{c}{ Grade (\%) } & \multirow{2}{*}{$\mathrm{CaF}_{2}$ Recovery (\%) } \\
\cline { 4 - 6 } & & & $\mathrm{CaF}_{2}$ & $\mathrm{SiO}_{2}$ & $\mathrm{CaCO}_{3}$ & \\
$\mathrm{~A}$ & 0 & 33.0 & 84.0 & 2.46 & 1.42 & 83.0 \\
& 500 & 29.2 & 96.4 & 1.41 & 0.75 & 85.0 \\
& 750 & 31.0 & 93.8 & 2.99 & 1.30 & 86.0 \\
\hline \multirow{2}{*}{$\mathrm{B}$} & 0 & 22 & 95 & 0.32 & 2.29 & 80.6 \\
\hline
\end{tabular}

The increase in the $\mathrm{CaF}_{2}$ grade with increasing $\mathrm{NaF}$ dosage observed for ore $\mathrm{A}$ is consistent with the findings made by [4], who concluded that $\mathrm{NaF}$ improved fluorite selectivity in the rougher cells. The authors [4] proposed that the $\mathrm{NaF}$ and collector interact, forming fluorine-bearing associates which have a higher affinity for fluorite than gangue minerals, e.g., carbonates and sulphates. They also suggested that fluorite activation is a result of the restructuring of the fluorite surface layer under the influence of the excess $\mathrm{F}^{-}$ions generated from the $\mathrm{NaF}$ addition. Both mechanisms should result in increased fluorite recovery and selectivity. However, the results presented in Table 6 suggest that there was an optimum dosage $(500 \mathrm{~g} / \mathrm{t} \mathrm{NaF})$ at which the $\mathrm{CaF}_{2}$ grade was maximum and gangue contamination was minimum for ore A. The results in Table 6 also indicate that $\mathrm{NaF}$ depresses the gangue at low dosages. This is evidenced by the drop in the gangue content, coupled with a significant increase in the $\mathrm{CaF}_{2}$ product grade by the addition of $500 \mathrm{~g} / \mathrm{t} \mathrm{NaF}$. It can be therefore concluded that $\mathrm{NaF}$ functions both as a fluorite activator and gangue depressant at low dosages.

For ore $\mathrm{B}$, the $\mathrm{CaF}_{2}$ grade just dropped by the addition of $500 \mathrm{~g} / \mathrm{t}$ of NaF. The results seem to suggest that the $500 \mathrm{~g} / \mathrm{t} \mathrm{NaF}$ dosage was already higher than the optimum NaF dosage. It is therefore recommended that lower $\mathrm{NaF}$ dosages be investigated to establish the optimum NaF dosage that would give the best metallurgical benefits in terms of $\mathrm{CaF}_{2}$ grade and recovery for ore $\mathrm{B}$.

At high $\mathrm{NaF}$ dosages, the excess fluorine-bearing associates formed from the interaction between the excess $\mathrm{NaF}$ and collector may unselectively adsorb onto the gangue minerals. Thus, the gangue minerals become floatable, hence the observed increase in silica and calcite contamination. Neutralisation or passivation of the $\mathrm{Ca}$ sites on the fluorite mineral surface by excess $\mathrm{F}^{-}$may also occur, such that there 
are no longer any $\mathrm{Ca}$ sites available on the fluorite mineral surface to bond with the collector on the fluorite surface, hence the loss in $\mathrm{CaF}_{2}$ recovery at high $\mathrm{NaF}$ dosages.

\subsection{Effect of Sodium Silicate Dosage for Ore A}

The effect of adding sodium silicate as a silicate depressant in an attempt to reduce silica content to below $1 \%$ in the concentrate was investigated in the rougher flotation cell and the results are shown in Table 7. It is clear from Table 7 that only a slight improvement in silica depression was achieved by increasing sodium silicate dosage from 0 to $310 \mathrm{~g} / \mathrm{t}$. A further increase in the sodium silicate dosage to $390 \mathrm{~g} / \mathrm{t}$ resulted in the targeted silica contamination of the less than $1 \%$ in the concentrate. However, this this was accompanied by significant loss in $\mathrm{CaF}_{2}$ recovery. The $\mathrm{CaF}_{2}$ recovery loss at a high sodium silicate dosage could be attributed to both reduced mass pull and the depression of the fluorite grains that are associated with silica gangue minerals, as revealed by the mineralogical analysis as shown in Table 8. The lower sodium silicate dosage was therefore not strong enough to depress the silica associated with the fluorite particles. Mineral association data are derived from shared boundaries amongst the identified mineral grains, therefore the higher the associated percentage is, the greater the degree of boundary-sharing between mineral species. In Table 8, it is clear that there exists some fluorite association with silicate minerals such as calcite, dolomite, pyroxene, K-feldspar and quartz, which ultimately resulted in $\mathrm{CaF}_{2}$ recovery loss when the depressant dosage was increased. This result indicates that there is an opportunity to explore other silicate depressants in an attempt to maximise the $\mathrm{CaF}_{2}$ recovery to the product.

Table 7. Effect of sodium silicate on $\mathrm{CaF}_{2}$ grade and recovery.

\begin{tabular}{cccccc}
\hline \multirow{2}{*}{$\mathbf{N a}_{2} \mathrm{SiO}_{3}$ Dosage (g/t) } & Mass Pull (\%) & \multicolumn{3}{c}{ Grade (\%) } & \multirow{2}{*}{ CaF $_{2}$ Recovery (\%) } \\
\cline { 3 - 5 } & & $\mathrm{CaF}_{\mathbf{2}}$ & $\mathbf{S i O}_{\mathbf{2}}$ & $\mathrm{CaCO}_{\mathbf{3}}$ & \\
\hline 0 & 29.2 & 96.4 & 1.63 & 1.49 & 83.0 \\
310 & 28.2 & 96.5 & 1.41 & 0.75 & 85.0 \\
390 & 24.5 & 97.4 & 0.92 & 0.60 & 73.2 \\
\hline
\end{tabular}

Table 8. Mineral associations between fluorite and gangue minerals in mass \%.

\begin{tabular}{cccc}
\hline Mineral Name & Fluorite & Calcite & Dolomite \\
\hline Free surface & 66.23 & 60.69 & 13.24 \\
Fluorite & 0.00 & 14.98 & 2.46 \\
Pyrite & 0.02 & 0.04 & 0.01 \\
Barite & 0.10 & 0.01 & 0.02 \\
Pyroxene & 2.79 & 2.41 & 0.89 \\
K-Feldspar & 0.15 & 0.18 & 0.03 \\
Biotite & 0.10 & 0.11 & 0.03 \\
Quartz & 0.83 & 0.76 & 0.27 \\
Fe oxides & 0.29 & 0.04 & 0.04 \\
Calcite & 28.22 & 0.00 & 82.93 \\
Dolomite & 1.16 & 20.69 & 0.00 \\
Others & 0.10 & 0.10 & 0.08 \\
\hline
\end{tabular}

\subsection{Effect of Concentrate Regrind for Ore B}

The results so far have demonstrated that it is possible to produce an acid-grade product with at least $96 \% \mathrm{CaF}_{2}$. However, the $\mathrm{S}$ content in the $\mathrm{CaF}_{2}$ concentrate was well above the market specification of $0.03 \%$. The high $\mathrm{S}$ content could be attributed to the association of fluorite grains with sulphide minerals as shown from the mineralogical analysis of the $\mathrm{CaF}_{2}$ concentrate presented in Table 9. 
Table 9. Fluorite concentrate sulphide mineral association in mass \%.

\begin{tabular}{cc}
\hline Mineral & Sulphide Mass $\%$ \\
\hline Free surface & 51.2 \\
Serpentine & 0.22 \\
Pyroxene & 0.63 \\
Feldspar & 0.10 \\
Mica & 0.47 \\
Quartz & 0.79 \\
Fe oxides & 2.88 \\
Fluorite & 23.7 \\
Carbonates & 13.1 \\
Apatite & 0.10 \\
Others & 6.80 \\
Total & 100 \\
\hline
\end{tabular}

Table 9 shows that $24 \%$ of the sulphides were associated with fluorite grains and hence the effect of concentrate regrinding on the sulphur content in the $\mathrm{CaF}_{2}$ concentrate was investigated and the results are shown in Figure 6 and Table 10.

To avoid grinding finer than the market's product PSD specification of $80 \%$ passing $65 \mu \mathrm{m}$, a milling curve was constructed, which showed that the regrind time of 8 min produced a product with a PSD coarser than a $\mathrm{P}_{80}$ of $65 \mu \mathrm{m}$. The milling curve showed that a regrind time of $1 \mathrm{~min}$ was required to achieve a $\mathrm{P}_{80}$ of $90 \mu \mathrm{m}$. Two cleaner concentrates were therefore independently ground for 1 and 2 min. Figure 6 shows that concentrate regrinding reduced both the $\mathrm{CaF}_{2}$ recoveries and grades. The drop in $\mathrm{CaF}_{2}$ recoveries could be due to the slower floating finer particles generated during the concentrate regrind. The drop in the grade of the $\mathrm{CaF}_{2}$ concentrate grade could be due to both the increased liberation of floatable gangue, such as calcite and entrainment of fine gangue particles. The results in Table 9 also indicate that concentrate regrinding resulted in reduced $\mathrm{S}$ content reporting to the $\mathrm{CaF}_{2}$ concentrate. However, the $\mathrm{S}$ content was still above the market specification of $0.03 \%$. Overall, concentrate regrinding had a detrimental effect of concentrate dilution by calcite as well as reduced $\mathrm{CaF}_{2}$ recovery. It was also observed that with longer regrinding time, the total sulphur content increased. It is therefore clear that the processing of ore B without regrind was still the best, though sulphur content was still off-spec.

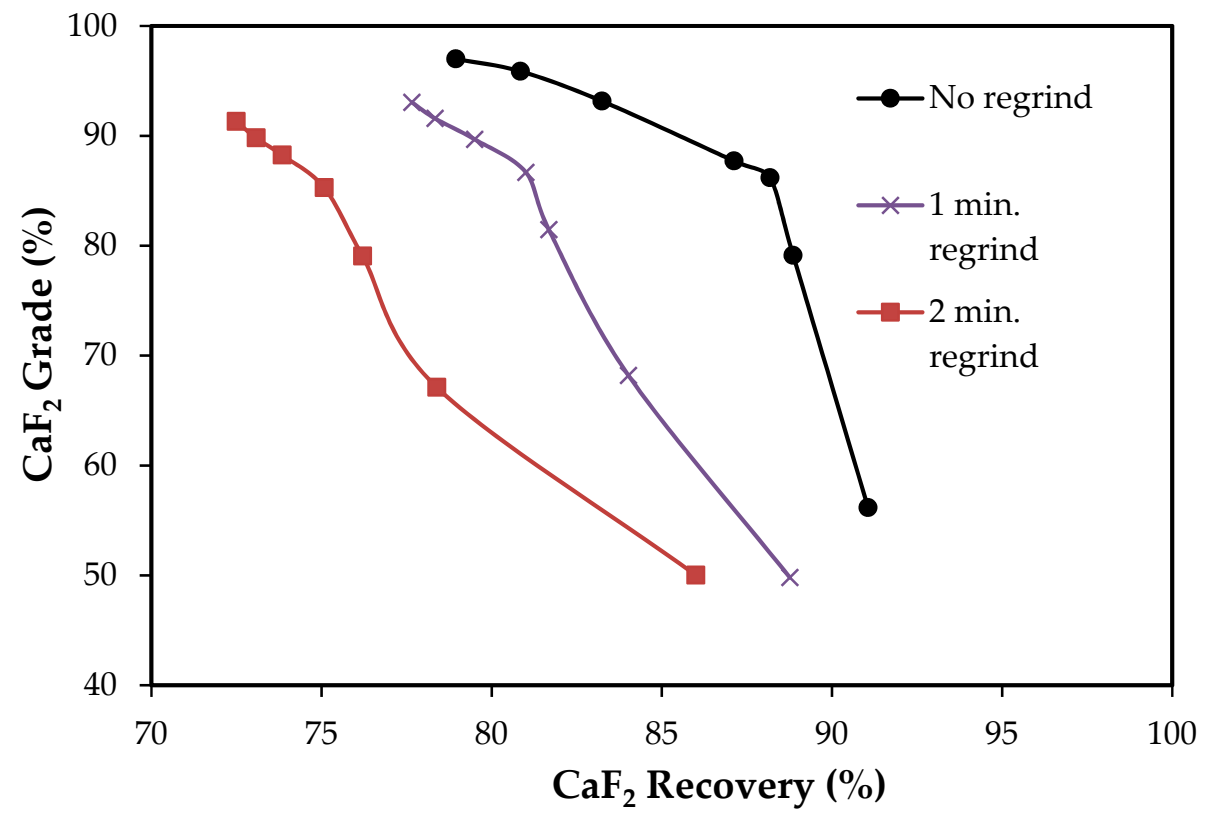

Figure 6. Effect of concentrate regrind on $\mathrm{CaF}_{2}$ grade and recovery. 
Table 10. Effect of concentrate regrind on $\mathrm{CaF}_{2}$ grade and recovery.

\begin{tabular}{ccccc}
\hline \multirow{2}{*}{ Regrind Time (minutes) } & \multicolumn{3}{c}{ Grade (\%) } & \multirow{2}{*}{ CaF $_{2}$ Recovery (\%) } \\
\cline { 2 - 4 } & $\mathrm{CaF}_{\mathbf{2}}$ & $\mathrm{CaCO}_{3}$ & $\mathbf{S}$ & \\
\hline 0 (no regrind) & 97.2 & 3.51 & 0.07 & 78.9 \\
1 & 93.4 & 3.72 & 0.06 & 77.6 \\
2 & 91.3 & 4.26 & 0.59 & 72.4 \\
\hline
\end{tabular}

\subsection{Effect of Lignin Sulphonate (Pionerra F250) Dosage on Sulphur Reduction for Ore B}

Further flotation testwork was conducted using lignin sulphonate (Pionerra F250) as a sulphide depressant with no regrind with a view to reduce the $\mathrm{S}$ content to the industry specification of $0.03 \%$. The depressant dosages were varied from 170 to $210 \mathrm{~g} / \mathrm{t}$ and the results are presented in Table 11 . It is clear from Table 11 that an increase in lignin sulphonate dosage resulted in a decrease in the total sulphur in the $\mathrm{CaF}_{2}$ concentrate from $0.07 \%$ to $0.02 \%$. Therefore, the acid-grace concentrate specifications were met in terms of both $\mathrm{CaF}_{2}$ and $\mathrm{S}$ grades, although this was accompanied by a $7 \%$ loss in $\mathrm{CaF}_{2}$ recovery. It can be concluded that the stage addition sulphide depressants in the rougher and cleaning stages in the processing of fluorite ores having high sulphur content is necessary to control the sulphur content in the concentrate.

Table 11. Effect of lignin sulphonate depressant on $\mathrm{S}$ grade as well as $\mathrm{CaF}_{2}$ grade and recovery.

\begin{tabular}{cccccc}
\hline \multirow{2}{*}{ Lignin-Sulphonate (g/t) } & \multirow{2}{*}{ Mass Pull (\%) } & \multicolumn{3}{c}{ Grade (\%) } & \multirow{2}{*}{ CaF $_{2}$ Recovery (\%) } \\
\cline { 3 - 5 } & & $\mathbf{C a F}_{\mathbf{2}}$ & $\mathbf{S i O}_{\mathbf{2}}$ & $\mathbf{S}$ & \\
\hline 170 & 23 & 97.1 & 0.25 & 0.07 & 78.9 \\
210 & 20 & 96.5 & 0.80 & 0.02 & 72.0 \\
\hline
\end{tabular}

The observed loss in $\mathrm{CaF}_{2}$ recovery could be attributed to the depression of the sulphide minerals that are associated with the fluorite. To investigate this, mineralogical analysis was conducted on the concentrate to further understand the association of the minerals present in the ore, and the results are shown in Table 9 . Table 9 shows that $37 \%$ of the sulphides were associated with fluorite and carbonates, while $7 \%$ of the sulphides were associated with other minerals. This observation shows that $\mathrm{CaF}_{2}$ recovery loss was inevitable if the $\mathrm{S}$ content in the final concentrate is to be reduced using a sulphide depressant.

\section{Conclusions}

This study investigated the role of gangue mineralogy on flowsheet and reagent regime selection on the processing of two different fluorite ores. One ore had higher quartz and calcite contents while the other had higher pyrite and dolomite contents. Customised flowsheets and efficiently optimised reagent regimes were investigated for the optimum production of acid-grade fluorite for each ore by the froth flotation process. An increase in pulp temperature resulted in increased $\mathrm{CaF}_{2}$ recovery but decreased $\mathrm{CaF}_{2}$ grade for both ores. The results therefore show that the fatty acid collectors can be effectively used in fluorite flotation to produce acid-grade $\mathrm{CaF}_{2}$ concentrate at ambient pulp temperatures. High selectivity at low pulp temperatures eliminates the need for high-temperature pulp treatment and thus translates to a significant reduction in thermal energy costs.

This study showed that gangue mineralogy plays a very important role in flowsheet and reagent regime selection on the processing of the different fluorite ores. Although an acid-grade $\mathrm{CaF}_{2}$ concentrate could be obtained from both ores, the flowsheets and reagent regimes were markedly different. Multiple stages of cleaning were required for improved selectivity in the flotation of both ores. Production of an acid-grade $\mathrm{CaF}_{2}$ product from a high quartz and calcite ore was achieved by employing a simple rougher-multiple cleaner flotation circuit using tannin and sodium silicate as calcite and quartz depressants, 
respectively. On the other hand, the production of an acid-grade $\mathrm{CaF}_{2}$ product flotation of the pyritic ore required a pre-sulphide flotation stage for upfront sulphur removal and a sulphide depressant during cleaning to meet the market specification with regards to sulphur content. The results showed that an understanding of gangue mineralogy is key to process optimisation for acid-grade $\mathrm{CaF}_{2}$ production.

Author Contributions: J.T., K.C.T., and P.N. conceived the research idea and designed the experiments; K.C.T. and P.N. conducted the experiments; J.T., K.C.T., and P.N. analysed the results; J.T. interpreted the data; J.T. wrote the paper. All authors have read and agreed to the published version of the manuscript.

Funding: This research received no external funding.

Acknowledgments: The authors would like to acknowledge Mintek's commercial clients for granting the permission to publish information gained from the testwork. Support from the Mineral Processing Division's technical team at Mintek is greatly appreciated.

Conflicts of Interest: The authors declare no conflict of interest.

\section{References}

1. Magotra, R.; Namga, S.; Singh, P.; Arora, N.; Srivasta-va, P.K. A new classification scheme of fluorite deposits. Int. J. Geosci. 2017, 8, 599-610. [CrossRef]

2. Crozier, R.D. Flotation, Theory, Reagents and Ore Testing; Pergamon: Oxford, UK, 1992.

3. Zhang, Y.; Song, S. Beneficiation of fluorite by flotation in a new chemical scheme. Min. Eng. 2003, 16, 597-600. [CrossRef]

4. Kienko, L.A.; Samatova, L.A.; Voronova, O.V.; Komdrat'ev, S.A. Lower temperature flotation of carbonatefluorite ores. J. Min. Sci. 2010, 46, 317-323. [CrossRef]

5. Zhou, Q.; Lu, S. Acidized sodium silicate-An effective modifier in fluorite flotation. Min. Eng. 1992, 5, 435-444. [CrossRef]

6. Ren, Z.; Yu, F.; Gao, H.; Chen, Z.; Peng, Y.; Liu, L. Selective separation of fluorite, barite and calcite with valonea extract and sodium fluorosilicate as depressants. Minerals 2017, 7, 24. [CrossRef]

7. Rutledge, J.; Anderson, C.G. Tannins in mineral processing and extractive metallurgy. Metals 2015, 5, 1520-1542. [CrossRef]

8. Zhou, W.; Moreno, J.; Torres, R.; Valle, H.; Song, S. Flotation of fluorite from ores by using acidized water glass as depressant. Min. Eng. 2013, 45, 142-145. [CrossRef]

9. Zhang, G.; Gao, Y.; Chen, W.; Liu, D. The role of water glass in the flotation separation of fine fluorite from fine quartz. Minerals 2017, 157, 157. [CrossRef]

10. Liu, R.Q.; Sun, W.; Hu, Y.H.; Wang, D.Z. Effect of organic depressant lignosulfonate calcium on separation of chalcopyrite from pyrite. J. Cent. South Univ. Technol. 2009, 16, 753-757. [CrossRef]

11. Kongolo, K.; Kipoka, M.; Minanga, K.; Mpoyo, M. Improving efficiency of oxide-cobalt ores flotation by combination of sulphidisers. Min. Eng. 2003, 16, 1023-1026. [CrossRef]

12. Taguta, J.; O'Connor, C.T.; McFadzean, B. The effect of alkyl chain length and ligand type of the enthalpy of adsorption and floatability of sulphide minerals. Min. Eng. 2017, 110, 145-152. [CrossRef]

13. Parkins, E.J. Effect of Temperature on the Conditioning and Flotation of an Ilmenite Ore. Ph.D. Thesis, London University, London, UK, 1975. 